UDK 316.7:39(497.11)"2014/2018”

doi: $10.5937 /$ bastina1949419S

Pregledni rad

Branislav S. SANČANIN*

Faculty of management, Sremski Karlovci, University "Union - Nikola Tesla", Belgrade, Serbia

Sandra V. DRAMIĆANIN**

Faculty of Hotel Management and Tourism, Vrnjačka Banja, University of Kragujevac

\title{
THE SIGNIFICANCE OF THE REPRESENTATIVE LIST OF THE INTANGIBLE CULTURAL HERITAGE FOR THE PRESERVATION OF SERBIAN CULTURAL HERITAGE
}

\begin{abstract}
With its uniqueness and openness for other cultures, Serbian culture is built upon a rich heritage and notable achievements. Thus, it has left a mark outside of the country's borders. The Slava was inscribed on the UNESCO Representative List of the Intangible Cultural Heritage in Paris. This occurred during the ninth session of the Intergovernmental Committee for the Safeguarding of the Intangible Cultural Heritage which took place from November 24 to 28, 2014. The Slava, thus, became a part of the global cultural heritage and the Republic of Serbia's first cultural good. The decision to inscribe Kolo, traditional folk dance was made on the December 4-9, 2017 session in South Korea. Then as a symbol of Serbian national identity, Singing to the accompaniment of the Gusle became the third inscribed element. This element was chosen during the thirteenth session of the Intergovernmental Committee for the Safeguarding of the Intangible Cultural Heritage in the Republic of Mauritius from November 26 to December 1, 2018.
\end{abstract}

Key words: UNESCO, Kolo, Slava, Gusle, cultural heritage.

\section{INTRODUCTION}

Culture is an essential aspect of the social existence and development. The diverse inventions, preservation and promotion of the centuries-old cultural heritage are the irreplaceable catalysts for development. The process of forming, strengthening, and expanding the national identity is only possible if one examines their culture and art. They also have to interpret multiple aspects of their correlation and mutual impact (Cvetković 2019).

\footnotetext{
* Professor of Professional Practice, branislav.sancanin@famns.edu.rs

** Ph.D.Student, sandradramicanin@hotmail.com
} 
The cultural heritage is either tangible or intangible. The tangible cultural heritage is divided into the immovable (including monuments of culture, archeological sites, and historic places) and movable (refers to museum, archival, audiovisual, photographic, and library materials). On the other hand, the intangible cultural heritage encompasses oral traditions, performing arts, craftsmanship, myths, rituals, festive events, and special clothing (Avramović 2014).

Emphasizing that collective memory, historical consciousness, and tradition are pillars of identity, (Inđić 2014: 386) writes that "we all rely on what our predecessors bequeathed to us. The past experiences become part of the future. For this reason, cultural politics strive to safeguard, protect, and research the cultural heritage."

Since its inception in 1945, the United Nations Educational, Scientific and Cultural Organization (UNESCO) has taken on the role of preserving and protecting the world artistic heritage and monuments of historical and scientific significance. At the same time, UNESCO can recommend which acts should come into force in order to fulfill its obligations in a timely manner. ${ }^{1}$

The Council of Europe defines the cultural heritage as "a group of resources inherited from the past which people identify, independently of ownership, as an expression of their constantly evolving values, beliefs, knowledge and traditions. A heritage community consists of people who value specific aspects of cultural heritage which they wish, within the framework of public action, to sustain and transmit to future generations" (Council of Europe 2005: 2).

The intangible cultural heritage refers to "the practices, representations, expressions, knowledge, skills, as well as to the instruments, objects, artifacts and cultural spaces associated with them - that communities, groups and, in some cases, individuals recognize as part of their cultural heritage. This intangible cultural heritage, transmitted from generation to generation, is constantly recreated by communities and groups in response to their environment, their interaction with nature and their history, and provides them with a sense of identity and continuity, thus promoting respect for cultural diversity and human creativity" (UNESCO 2003: 2).

Article 2 of the Convention for the Safeguarding of the Intangible Cultural Heritage is extremely significant for the Republic of Serbia as it emphasizes the unbreakable bond between the cultural spaces and the intangible cultural heritage.

"We have now good examples of interactions between the lists of the 2003 Convention and the List of the 1972 Convention: this is the case of Dubrovnik

1 The Constitution of UNESCO, signed on 16. November 1945, came into force on 4. November 1946 after ratification by twenty countries: Australia, Brazil, Canada, China, Czechoslovakia, Denmark, Dominican Republic, Egypt, France, Greece, India, Lebanon, Mexico, New Zealand, Norway, Saudi Arabia, South Africa, Turkey, United Kingdom, United States. 
(added to the World Heritage List) and the Festivity of Saint Blaise, the patron of Dubrovnik (included on the Representative List of Intangible Cultural Heritage)" (Krause 2011: 13).

The intangible cultural heritage isn't necessarily limited to the non-physical things. Namely, it encompasses objects and nature which are directly connected to the intangible values. Insisting that the intangible cultural heritage has to closely interact with the fundamental human rights points to intolerance. This intolerance is reflected towards expressions and customs which involve sacrifices, mutilation, etc. (Blake 2006: 36).

One of the most important characteristics of the intangible cultural heritage is that it is dynamic. This is a desired quality to have in order to sustain for a long time. However, it can also present a threat in the upcoming period due to the globalization and the inevitable influence of stereotypes. Safeguarding Serbian cultural and historical heritage is paramount because of globalization. This proves the heritage's long duration because "disputing the identity and history of Serbs has been present since the nation's inception” (Petrović - Dostić 2019: 416).

All of us participate in and contribute to the preservation of the heritage every day. The intangible cultural heritage is inherent in anyone who recognizes themselves in it. It is necessary to say that the intangible cultural heritage is both urban and rural (Todorović 2011).

In the foreseeable future we should expect theoretical and scientific explanations of the intangible cultural heritage from the perspective of UNESCO. Additionally, we should expect the same for the intellectual property in traditional culture from the World Intellectual Property Organization (WIPO). Both of these organizations promote different ways of claiming full rights over culture. Today, the two organizations secure the preservation of the heritage. In other words, UNESCO inscribes and safeguards, while the WIPO solves questions of ownership and exchange.

The UNESCO list of the intangible cultural heritage includes those which are in dire need of protection. Then, it features the Representative List of the Intangible Cultural Heritage of Humanity and the Register of Best Safeguarding Practices. It numbers 508 elements corresponding to 122 countries (UNESCO 2018a).

\section{SAFEGUARDING THE INTANGIBLE CULTURAL HERITAGE}

Despite the increasing impact of globalization and the blatant favoritism of tangible over intangible, many cultures have managed to preserve and value their intangible cultural heritage. They place the same value in it as they do in the tangible cultural heritage. Consequently, this attitude towards the heritage has increased the interest of individuals and numerous international organizations in how to preserve the intangible cultural heritage. 
A number of conventions which focus on protecting and preserving the cultural heritage were adopted under the auspices of UNESCO:

- The Hague Convention for the Protection of Cultural Property in the Event of Armed Conflict (1954);

- The Convention on the Means of Prohibiting and Preventing the Illicit Import, Export and Transport of Ownership of Cultural Property (1970);

- The Convention on Stolen or Illegally Exported Cultural Objects - UNI$\operatorname{DROIT}^{2}(1995)$;

- The Convention Concerning the Protection of the World Cultural and Natural Heritage (1972) and

- The Convention for the Safeguarding of the Intangible Cultural Heritage (2003).

Each of the five conventions present an answer to the then serious threats to the cultural heritage. It was impossible to avoid thematic overlaps to a certain degree while drafting them.

UNESCO has a leading role in the protection and promotion of the intangible cultural heritage. The the unstoppable globalization process and cultural diversity are mentioned in three conventions:

- The Universal Declaration on Cultural Diversity (2001);

- The Convention for the Safeguarding of the Intangible Cultural Heritage (2003);

- The Convention for the Protection and Promotion of the Diversity of Cultural Expressions (2005).

\section{THE CONVENTION FOR THE SAFEGUARDING OF THE INTANGIBLE CULTURAL HERITAGE}

The UNESCO General Conference adopted the Convention for the Safeguarding of the Intangible Cultural Heritage on October 17, 2003, in Paris. It came into force on April 20, 2006, after the thirtieth instrument of ratification was deposited. ${ }^{3}$

The 2003 Convention was successfully ratified by 130 member states and all UNESCO member states in the Southeast Europe - particularly since June 2010, when Serbia ratified it as well (Krause 2011:15).

The ratification of the Convention for the Safeguarding of the Intangible Cultural Heritage was a consequence of realization that the then-known instruments

2 UNIDROIT - International Institute for Unification of Private Law.

3 The Convention for the Safeguarding of the Intangible Cultural Heritage was drawn up in Arabic, English, Chinese, Russian, French, and Spanish, the six texts being equally authoritative. 
for the cultural heritage and intellectual property protection couldn't quite secure the intangible cultural heritage.

The intangible cultural heritage can be manifested in different ways. However, these ways are not inexhaustible despite their scope and diversity. They are visible in the below domains (UNESCO, 2003):

- Oral traditions and expressions, including language as a vehicle of the intangible cultural heritage;

- Performing arts;

- Social practices, rituals and festive events;

- Knowledge and practices concerning nature and the universe;

- Traditional craftsmanship.

Member states have a task to identify and define the intangible cultural heritage. They are also entrusted with the task of taking every measure to ensure its preservation and protection.

The intangible heritage should be perceived as a step forward from the territorial boundaries. That is, a relationship between the intangible heritage and those who protect and promote it isn't established with a help of a country or territory (Hafstein 2013). We can prove this statement through the intangible and tangible dimension. Čedomir Rebić reminds us of this as well. He points to the books written at the end of 17 th and beginning of 18th century in the Kingdom of Hungary. According to him, they were more reminiscent of the medieval Serbian literary tradition than of that kingdom. The books put the events in the temporal and spatial context of the conflict "between the Byzantine heritage and the Western culture which relied on the Latin language" (2012: 12).

In order to implement the Convention effectively and efficiently, the General Assembly adopted the Operational Directives for the Implementation of the Convention for the Safeguarding of the Intangible Cultural Heritage at its second session. The Directives are revised every two years. The Operational Directives teach the member states to form groups. They should be comprised of experts and community members who would identify and define the elements of the intangible cultural heritage. In addition, they would prepare lists and remove certain elements from the national list.

The purpose of the Convention for the Safeguarding of the Intangible Cultural Heritage are (UNESCO 2003):

- to safeguard the intangible cultural heritage;

- to ensure respect for the intangible cultural heritage of the communities, groups and individuals concerned;

- to raise awareness at the local, national and international levels of the importance of the intangible cultural heritage, and of ensuring mutual appreciation thereof;

- to provide for international cooperation and assistance. 
The term "safeguard" denotes measures aimed at securing the viability of the intangible cultural heritage. This includes the identification, documentation, research, preservation, promotion, evaluation, transmission, and the revitalization of different heritages.

The revitalization brought about certain dilemmas in some states. In other words, they weren't sure whether the term meant that they should artificially recreate past and forgotten customs and traditions or if they should modernize others. However, if we were to examine the term carefully, we would conclude that it referred to the present heritage - not past (Blake 2006).

There are considerable advantages of the intangible over tangible heritage, as proven by historical and conservation analyses. Because of the nature of the intangible heritage, many nations have preserved their long-standing history and traditions; even though they have gone through turmoil, wars, and various natural disasters. Also, museum curators have realized that it is impossible to stop the decay of objects. On the other hand, the intangible cultural heritage isn't susceptible to or under the influence of the relentless process of decay (Popović Živančević 2011).

The fifth chapter of the Convention is of paramount importance. It serves to provide assistance to the developing countries which possess the valuable intangible cultural heritage. They can opt for the type of international assistance they need.

\section{NATIONAL FRAMEWORK FOR THE PRESERVATION AND PROTECTION OF THE INTANGIBLE HERITAGE}

Every member state has to identify and define the elements of the intangible cultural heritage which are present within its territory. This is done with the help of communities, groups and relevant non-governmental organizations (UNESCO 2003).

The Cultural Property Law of Serbia doesn't mention the term "the intangible cultural heritage," although Serbia ratified the UNESCO Convention for the Safeguarding of the Intangible Cultural Heritage.

The National Assembly of the Republic of Serbia adopted the Convention on May 5, 2010. UNESCO received the instrument of ratification on May 30, 2010. After three months, Serbia became the full-fledged member of the Convention (Drača Muntean 2011).

The Ministry of Culture and Information of Serbia accepted the UNESCO directives and guidelines, establishing the basic system for protecting and safeguarding the intangible cultural heritage. It formed the national network for the protection of the intangible cultural heritage. The network is comprised of the National Committee for the Intangible Cultural Heritage, the Center for the 
Intangible Cultural Heritage of Serbia at the Ethnographic Museum in Belgrade, the Commission for Inscription of the Intangible Cultural Heritage in the Registry, and seven regional coordinators for the protection of the intangible cultural heritage (for Vojvodina, Belgrade, Western, Eastern, and Central Serbia, and Kosovo and Metohija). Also, a special department for the intangible cultural heritage was formed at the National Museum in Zaječar. And the "Old Village" Museum in Sirogojno is the education center for traditional craftsmanship. The Center for the Intangible Cultural Heritage created the intangible cultural heritage registry (the Ministry of Culture and Information 2017).

The proposers of the elements to be added to the intangible cultural heritage of Serbia list can be individuals, institutions, non-governmental organizations, and local communities. They have to provide the relevant documentation. The deadlines are determined by the National Committee for the Intangible Cultural Heritage.

The list of elements of the intangible cultural heritage of the Republic of Serbia includes 46 entries (National Committee for the Intangible Cultural Heritage 2018): Saint Patron’s Day; Prayer - St. George’s Day ritual; Belmuž; Ritual of making and lighting farmer candles; Making of Pirot hard cheese; Rug-making in Pirot; Craft of filigree work, master Krist Beriša, silversmith from Kraljevo; Craft of stonemasonry, Bela Voda; Pazar meat pie prepared in traditional way; Zlakusa pottery; Kosovo-style embroidery; Singing to the accompaniment of the Gusle; Groktalica singing; Clamor singing; Era-style humor; Kolo dance, three-steps kolo, six-steps kolo; Rumenka kolo dance; Bagpipe playing; Pipe-playing practice; Kaval Playing; Slovak naive art painting; Lazarica processions from Sirinićka Župa; Wooden flask making in Pilica village; Vuk's Convocation; Ojkača singing; Urban songs from Vranje; Easter Ritual of Guarding Jesus Christ's Tomb; Pirot storytelling; St. George; Plum brandy; Craft of coppersmith; Rug-making in Stapar; Kajmak making; Cipovka - konwledge and skills in preparing traditional bread in Vojvodina; Cooking žmare, “žumijar”; Bela vila - Easter customs in Velika Hoča; Burning of Petrovdan "lila" torches, lilanje; Toasts; Opanak-making craft; Double-stranded knitting of woolen socks; Singing along a bee swarm; Bezdan damast; Weaving bošča aprons; Prince Marko’s Wedding - carnival wedding at Štrpce; Vertep; Making of Sjenica-Pešter type of rugs.

The National Committee is a body of the Ministry of Culture which ensures the protection of the intangible cultural heritage and the implementation of the Convention for the Safeguarding of the Intangible Cultural Heritage.

The National Committee adjusts its work to the National Commission of the Republic of Serbia for UNESCO. It is through this Commission that the Committee delivers its recommendations for the Representative List of the Intangible Cultural Heritage of Humanity. In addition, it delivers its suggestions for the List of Intangible Cultural Heritage in need of immediate preservation from UNESCO. 


\section{THE CENTER FOR THE INTANGIBLE CULTURAL HERITAGE}

The Ethnographic Museum in Belgrade, a cultural institution of national importance, opened the Center for the Intangible Cultural Heritage on June 20, 2012. The Center's task is to research, catalogue, process, storage, and present the intangible cultural heritage in Serbia. Also, it assists local communities in identifying, evaluating, and transferring their own cultural heritage to future generations (Ethnographic Museum in Belgrade 2012).

The goal of the Center is to implement the intangible cultural heritage in economic development. In addition, it works with other organizations and institutions at home and abroad.

\section{SLAVA}

The Ethnographic Museum in Belgrade was in charge of preparing the nomination for a Slava (krsno ime, krsna slava). The slava was inscribed on the UNESCO's Representative List of the Intangible Cultural Heritage in Paris during the ninth session of the Intergovernmental Committee for the Safeguarding of the Intangible Cultural Heritage. It officially became a part of the world cultural heritage and it was the first Serbian cultural good to be inscribed.

The modern name Krsna slava (christened slava) was coined recently. Many believe that the term was derived from "christened name" and "christened slava” (Grujić 1985).

"Serbian Orthodox Christian families celebrate an important holiday which honors the patron saint who they believe is their protector and provider of welfare.

The festivities consist of the ritual offering of a bloodless sacrifice as well as a feast presented to relatives, neighbors, and friends.

The family lights a specially designed candle, then it pours wine over a Slava cake. The host's wife prepares and decorates the cake. During the ritual, thanks are given to the saint and prayers are said for prosperity. The host cuts the cake together with the oldest or most important guest and other family members. The feast then begins with the ceremonial drinking of wine, eating and a toast expressing wishes for health, fertility and well-being of the family and guests. However, some families take the Slava cake to church where a priest cuts it. Alternatively, a priest visits the family to cut the cake" (UNESCO 2014).

As the feast is the most important part, there is a posna or mrsna slava. If the first day of the slava falls on a Wednesday or Friday or during the Nativity Fast, then it will be a posna slava (no meat, dairy products, or eggs are served). The exceptions are those slavas which occur during "trapava sedmica" - a period 
when there is no fasting. During this time, the slava can be mrsna on a Wednesday or a Friday as well (Pavković 2015).

Knowledge about the slava is passed down in families. Here, women play an important role in protecting the tradition because they possess the knowledge regarding the performance of rituals, their meaning and purpose.

The celebration of saint patron is a characteristic of the Orthodox Christians. It plays an important role in the multiethnic and multiconfessional regions. Namely, it establishes and maintains interethnic and intercultural communication and understanding.

In Serbia the slava is a way of showing one's identity; although, the celebration of family saint patron's day can be found among other ethnic communities in Serbia.

\section{KOLO, TRADITIONAL FOLK DANCE}

The UNESCO Intergovernmental Committee for the Safeguarding of the Intangible Cultural Heritage inscribed Kolo, traditional folk dance on the Representative List of the Intangible Cultural Heritage. This occurred during the twelfth session from December 4 to 9, 2017, in South Korea (UNESCO 2017a).

The proposers of the traditional folk dance Kolo were the Faculty of Music, the Centre for Research and Preservation of Traditional Dances of Serbia, and the Folk Dance and Dance Ensemble of Serbia "Kolo." The nomination, based on the decision of the National Committee for the Intangible Cultural Heritage, was drafted at the Center for Intangible Cultural Heritage.

"Kolo is a traditional, collective folk dance. It is performed by dancers who are interlinked to form a chain. They usually move in a circular line while holding hands. It is performed to the accompaniment of music at private and public gatherings and involves all members of the local community. Cultural-artistic societies and folk dance groups are also important bearers and practitioners of the element. Kolo has an important integrative social function. Namely, it fosters collective identities at different levels in the communities. It is a symbol of national identity and bears the hallmark of local and regional communal identities. Performances during celebrations of the most important events in individuals' and communities' lives make this element very present and sustainable at all levels. Bearers and local communities ensure its visibility by organizing local, regional and national fairs, festivals and competitions, and the sustainability of the practice is also ensured by cultural and artistic societies. Learning through direct participation is the most common way of transmitting the skills and skilled dancers motivate other players, awakening in them a desire to learn and improve their own performance. Knowledge is also acquired through the regular education system and in ballet and music schools" (UNESCO 2017b). 
On October 4, 2015, around 12,000 dancers participated in the biggest folk dance in Novi Sad in order to break the Guinness World Record. Performers from all over Serbia and abroad took part. Members of 258 cultural-artistic societies, children, and adults from Serbia, Montenegro, Bosnia and Herzegovina, FYR Macedonia, Bulgaria, Italy, Hungary, Austria, and Germany danced.

\section{SINGING TO THE ACCOMPANIMENT OF THE GUSLE}

Singing to the accompaniment of the gusle is an element of the intangible cultural heritage of Serbia. It was inscribed on the Representative List of the Intangible Cultural Heritage of Humanity on November 29, 2018. This happened during the thirteenth session of the UNESCO Intergovernmental Committee in the Republic of Mauritius (UNESCO 2018b).

The National Committee for the Intangible Cultural Heritage nominated this element, while the Centre for Research and Preservation of Traditional Dances of Serbia prepared the document. The nomination was formed with the help of the Institute of Musicology SASA, the Union of Guslars of Serbia. Also, local government, regional cultural institutions, non-governmental organizations and individuals lent their support.

"Singing to the accompaniment of the gusle is a practice that includes singing of folk epic decasyllabic poems, performed by a singer to the accompaniment of the gusle - a one-stringed, exceptionally two-stringed, bowed string instrument. In the past, both the poetic texts and the musical component of guslar songs were transmitted orally, whereas today, the presented texts mostly include the well-known written ones.

This archaic form of folk art promotes the highest ethical values, the importance of kinship and the homogeneity of the community, and it is also a blend of the community's historical memory and traditional music skills. The communities that practice it consider it the most representative element of their identity.

Singing to the accompaniment of the gusle, as part of both performing arts and oral tradition, is present in the entire territory of Serbia. However, its practice is more pronounced in the western and central parts of Serbia and in Vojvodina" (National Committee for the Intangible Cultural Heritage 2012).

\section{CONCLUSION}

The world and intangible cultural heritage in Serbia is endangered because of numerous reasons, starting from natural disasters, human influence, and globalization's impact to the insufficient amount of social support. The international community has recognized the significance of the intangible cultural heritage, 
especially through the work of the United Nations Educational, Scientific and Cultural Organization. It adopted the Convention on the Safeguarding of the Intangible Cultural Heritage, although it delegated duties regarding identification, presentation, and registration to the national committees.

The inscription of Kolo, traditional folk dance, Slava, and singing to the accompaniment of the gusle on the UNESCO Representative List of the Intangible Cultural Heritage of Humanity is a significant step forward for Serbian culture. It means the intangible heritage of Serbia is recognizable and visible to the world.

Every future suggested concept of the protection of the cultural heritage should include its tangible, intangible, and natural contents. Only the integrative approach to the protection of the cultural and natural heritage can secure the sustainable development.

Apart from this, it is necessary to strengthen the small community of professionals and researchers so that they can respond to numerous challenges of protecting the intangible cultural heritage.

\section{REFERENCES}

Аврамовић 2014: Зоран Аврамовић. Основни елементи стретегије развоја српске културе, 377-388. Економски зборник - Моїће сйрет̄еіије развоја Србије. БеограА: Српска академија наука и уметности.

Blake 2006: Janet Blake. Commentary on the 2003 UNESCO Convention on the Safeguarding of the Intangible Cultural Heritage, Leicester: Institute of Art and Law.

Council of Europe 2005: Council of Europe. Framework Convention on the Value of Cultural Heritage for Society, Article 2 <https://rm.coe.int/1680083746> [May 20, 2018]

Цветковић 2019: Соња С. Цветковић. Синестиезија визуелної и музичкоі - Вићентиије Петирик: Мари Милоша С. Милојевића. Баштина (48), 387-398. Приштина - Аепосавић: Институт за српску културу

Арача Мунтеан 2011: Асја Арача Мунтеан. Потврђивање и имплементација Унескове конвенције о нематеријалном културном наслеђу у Републици Србији, 26 - 27. Немайеријално кулитурно наслеђе Србије. БеограА: Министарство културе, информисања и информационог Аруштва - Центар за заштиту нематеријалног наслеђа Ethnographic Museum in Belgrade 2012: Centre for the Intangible Cultural Heritage of Serbia $<$ https://etnografskimuzej.rs/en/o-muzeju/centar-za-nematerijalno-kulturnonasledje-srbije/> [Oktober 5, 2019]

Грујић 1985: Радослав Грујић. Црквени елемениеи Крсне славе, 407-485, БеограА: ОКИз Hafstein 2013: Valdimar Tr. Hafstein. Pravo na kulturu: nematerijalna baština d.o.o., folklor, tradicijsko znanje. Marijana Hameršak, Iva Pleše i Ana-Marija Vukušić (ed), Proizvodnja baštine: Kritičke studije o nematerijalnoj kulturi, 7-28, Zagreb: Institut za etnologiju i folkloristiku. Инђић 2014: Триво Инђић. Стретегија културне политике, 367-376. Економски зборникMoīyћ стирейеīuје развоја Србије. БеограА: Српска академија наука и уметности.

Kpayc 2011: Anthony Krause. The 2003 Convention for the safeguarding of intangible cultural heritage: Challenges and Perspectives, 15-19. Intangible cultural heritage of Serbia. Belgrade: Ministry of Culture, Media and information society - Center for safeguarding of the intanglble heritage 
Министарство културе и информисања 2017: Стратегија развоја културе Републике Србије оА 2017. Ао 2027., БеограА

National Committee for the Intangible Cultural Heritage 2012: Singing accompanied by gusle. <http://nkns.rs/en/popis-nkns/singing-accompanied-gusle> [May 6, 2018]

National Committee for the Intangible Cultural Heritage 2018: List of elements of intangible cultural heritage of the Republic of Serbia <http://nkns.rs/en/list-elements-intangible-cultural-heritage-republic-serbia-0> [Oktober 1, 2019]

Павковић 2015: Никола Ф. Павковић. Слава или Крсно име коА Срба, 123-145. БеограА: ГАасник Ейноірафскоі инстиййуйа САНУ LXIII (1).

Петровић - Аостић 2019: Аалибор Н. Петровић, Синиша Р. Аостић. Покушај оспоравања историјског наслеђа Цркве и постојања српског народа на примеру светог Стефана Штиљановића. Баштина (47), 415-428. Приштина - Иепосавић: Институт за српску кумтуру.

Поповић Живанчевић 2011: Мила Поповић Живанчевић. Музеји и нематеријална баштина, 32-48. Немайеријално кулитурно насиеђе Србије. БеограА: Министарство културе, информисања и информационог Аруштва - Центар за заштиту нематеријалног наслеђа.

Ребић 2012: ЧеАомир Ребић. Књижевна Ајематност на заласку старе српске књижевне траАиције. Баштина (32), 11-23. Приштина - Аепосавић: Институт за српску културу

Тодоровић 2011: Јелена Тодоровић. Разумевање нематеријалног културног наслеђа, 76-78. Нематеиеријално кулитурно наслеђе Србије. БеограА: Министарство културе, информисања и информационог Аруштва - Центар за заштиту нематеријалног наслеђа

UNESCO 2003: UNESCO. Text of the Convention for the Safeguarding of the Intangible Cultural Heritage; <https://ich.unesco.org/en/convention> [February 2, 2019]

UNESCO 2014: Slava, celebration of family saint patron's day. <https://ich.unesco.org/en/ $\mathrm{RL} /$ slava-celebration-of-family-saint-patrons-day-01010> [December 11, 2018]

UNESCO 2017a: Examination of nominations for inscription in 2017 on the Representative List of the Intangible Cultural Heritage of Humanity (item 11.b on the agenda). <https://ich.unesco.org/en/11b-representative-list-00939> [February 11, 2018]

UNESCO 2017b: Kolo, traditional folk dance <https://ich.unesco.org/en/RL/kolotraditional-folk-dance-01270 $>$ [December 12, 2018]

UNESCO 2018a: UNESCO Intangible Cultural Heritage. <https://ich.unesco.org/en/lists? multinational=3\&display1=inscriptionID\&display=stats\#tabs $>$ [Oktober 10, 2019]

UNESCO 2018b: Singing to the accompaniment of the Gusle. <https://ich.unesco.org/en/ $\mathrm{RL} /$ singing-to-the-accompaniment-of-the-gusle-01377> [Oktober 10, 2019] 
Бранислав С. САНЧАНИН

Сандра В. АРАМИЋАНИН

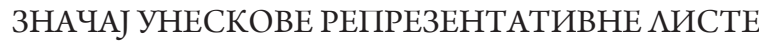 НЕМАТЕРИЈААНОГ КУАТУРНОГ НАСАЕБА ЗА ОЧУВАҢЕ КУАТУРНЕ БАШТИНЕ СРБИЈЕ}

\section{САЖЕТАК}

Српска култура се, својом аутентичношћу и истовременом отвореношћу за остале светске културе, темеьи на многобројном наслеђу и завидним креативним постигнућима, чиме је оставила неизбрисив траг знатно изван националних оквира. „Породична слава“ уписана је у седишту УНЕСКО-а у Паризу, на 9. засеАању Међувладиног комитета за заштиту нематеријалне културне баштине, одржаном оА 24. Ао 28. новембра 2014. године, на Унескову Репрезентативну мисту нематеријалног културног наслеђа. Тиме је формално постала део светске културне баштине, као првоуписано културно добро из Републике Србије на овој мисти. Унесков Међувладин комитет за очување нематеријалног културног наслеђа, на свом 12. засеАању оА 4. Ао 9. децембра 2017. године у Јужној Кореји, Аонео је одлуку о упису „Кола традиционалне народне игре“ на Унескову репрезентативну мисту нематеријалног културног наслеђа. На Унесковој Репрезентативној кисти нематеријалног културног наслеђа човечанства од 2018. године, као симбол српског националног памћења, налази се „Певање уз гусле“. ОАлука о томе донета је у Републици Маурицијус, где је од 26. новембра до 1. Аецембра 2018. године, оАржан 13. годишњи састанак Међувладиног комитета за очување нематеријалне културне баштине.

Кьучне речи: УНЕСКО, Комо, Слава, Гусле, Културно наслеђе.

Rad je predat 24. oktobra 2019. godine, a nakon mišljenja recenzenata, odlukom odgovornog urednika Baštine, odobren za štampu. 